\title{
Institutional Stability in Management Practice and Industrial Relations: The Influence of the Anglo- American Council for Productivity, 1948-52
}

\author{
Ian Clark
}

To cite this article: Ian Clark (1999) Institutional Stability in Management Practice and Industrial Relations: The Influence of the Anglo-American Council for Productivity, 1948-52, Business History, 41:3, 64-92, DOI: 10.1080/00076799900000308

To link to this article: https://doi.org/10.1080/00076799900000308

巴nublished online: 28 Jul 2006.

Submit your article to this journal $\square$

Џ Article views: 45

4 Citing articles: 4 View citing articles ๘ 


\title{
Institutional Stability in Management Practice and Industrial Relations: The Influence of the Anglo-American Council for Productivity, 1948-52
}

\author{
IAN CLARK \\ De Montfort University
}

The endurance of institutional stability in British industrial relations and management practice during the initial post-war years rested on two factors; the international viability of the British economy and the respite that victory in the Second World War afforded to embedded patterns of regulation in both areas. This paper addresses these factors through the vehicle of the Anglo-American Council for Productivity (AACP), and, specifically, its British section. The AACP was created to examine the issues of management practice and productivity in British manufacturing. The AACP aimed to transform management practice and raise levels of productivity in British manufacturing to those attained by the average American firm.' It follows from this that the success or failure of the AACP must be judged on the extent of its capability to transform management practice in the UK. Although American management practice informed the AACP's recommendations, the British section diluted American proposals to afford representatives of British employers and management an opportunity to secure institutional stability in management practice and industrial relations. Before proceeding to the historical narrative, brief comment is made on other pertinent analyses of the AACP. This is followed by a specification of how this contribution adds value to the existing literature. Lastly, the research methods that have been employed are briefly sketched.

The AACP has received much recent attention. Carew has examined the council as a propaganda vehicle designed to divide the European labour movement and inject a more American-scientific approach into British management practice. ${ }^{2}$ Carew suggests that the AACP was not primarily designed to transform British management practice, but is, alternatively, more appropriately understood within the emergent Cold War. ${ }^{3}$ Carew argues that Marshall Aid in general and the AACP in particular were both businessmen's programmes based on American values of free enterprise and, contrary to appearances, the interests of workers and organised labour 
were decidedly secondary. The immediate achievement of Marshall Aid was to finalise a growing split in the international labour movement and reinforce the anti-communist sentiments of US foreign policy. This approach follows an agenda that has recently been established by international relations scholars such as Hogan and Maier. ${ }^{4}$

In contrast, Tomlinson and Tiratsoo have examined the AACP within the framework of state intervention in the British economy between 1939 and $1945 .{ }^{5}$ Here it is concluded that while the British government was concerned with improving productivity and management practice it was more immediately concerned with and constrained by the UK's precarious balance of payments position. Both of these approaches concentrate on the failure of American recommendations to transform British management practice; however, they have relatively little to say on the specific issue of industrial relations.

In stark contrast to the above, Barnett has argued that the Labour government missed a clear opportunity to modernise and transform the British economy. ${ }^{6}$ This was the case because of its political determination to build a 'New Jerusalem' in civil society as opposed to modernising the British economy. In addition to this general criticism, the government is presented as a double failure; its domestic agenda was ill-conceived, but, further, the government embraced established patterns of behaviour in British management and class culture, including industrial relations. From this, Barnett holds that the government accepted the existing political framework, including great power status as evidenced by a reserve currency, maintenance of the sterling area, and voluntarism in management practice and industrial relations. This acceptance led the government to 'squander' Marshall Aid funds on a domestic housing programme and debt retirement. In defence of this argument, Barnett points out that only about nine per cent of British GNP was spent on investment goods in 1950, in comparison to 19 per cent in West Germany. ' In similar vein, Broadberry and Crafts have argued that the failure of the AACP to transform embedded patterns of industrial relations in the immediate post-war years is a central factor in explaining the UK's comparatively poor economic performance over the whole post-war period to date. ${ }^{8}$ In particular, they suggest that the intransigence of trade unions, in the forms of multi-unionism and restrictive practices prevented management from taking up many of the suggestions made by the AACP.

In contesting and contextualising the contributions of Barnett and Broadberry and Crafts, it is necessary to draw a sharp distinction between the AACP in general and its British section. This analysis will illustrate that representatives of employers and management within the British section played a significant role in sustaining embedded patterns of management 
practice and associated patterns of industrial relations. The AACP was a failure because the American section could not successfully position its arguments and findings in the British section. Thus, the notion of 'failure' has to be specified in two distinct ways; the failure of the AACP's overall prescription for improved management practice and productivity and why the British section considered the prescription inappropriate. This engagement is of value for two reasons. First, much of the established literature on the AACP begs the question of the objective criteria used for 'failure'. The idea of failure centres on the argument that the reconstruction of the British economy envisaged by the AACP did not occur. For longer term competitiveness such a failure may be one factor in the diagnosis of declining economic performance. However, the key issue is why the AACP was a short term failure. American proposals were rejected by the British section in large measure because they ignored short term economic constraints, for example shortages of capital and materials. Equally, American proposals, if implemented, would have reduced industrial output, and as a result threatened the international viability of the British economy.

Rather than an investment-led transformation of plant and equipment, international viability was secured through a recovery in output largely sustained by the existing capacity of plant and equipment. This approach was designed to correspond with the wider aims of the British government in the Marshall Plan and the recovery in output during the post-war years led to significant gains in labour productivity - the primary aim of the AACP. The AACP, though not necessarily its British section, was a failure because it was unable to find immediate or culturally acceptable ways to achieve a modernisation of management and industrial practice. It is plausible to argue that during the post-war years the AACP's British section sought to formulate short term solutions to the issue of productivity within the economic constraints that were imposed and accepted in order to secure the viability of the British economy.

A second contribution that adds value to the existing literature relates to the position of the conventional institutional approach to industrial relations. ${ }^{9}$ The approach details central features in the British system of industrial relations, in particular, the embedded nature of state abstention, autonomous and short-termist approaches in management practice and collective bargaining. However, the approach does not engage with the $\mathrm{AACP}$ as an institution, the British section in particular, (even though) the British section played a central role in securing wider institutional stability in industrial relations. This omission is of critical significance to the current interest in the AACP because it has enabled other literature sets to appropriate and generalise the UK's pattern of industrial relations as a singular factor of explanation in Britain's deteriorating economic 
performance over the post-war period. In addressing this omission it is not the intention to deny the need for institutional analysis but to strengthen its relevance.

An industrial relations system represents an institutional sub-set of a particular industrial society. The institutions and processes of job regulation, such as management, trade unions and collective bargaining, are not confined to the disciplines of economics and politics. ${ }^{10}$ Rather, the aims of management and employees in the employment relationship are more appropriately understood within a historically positioned institutional analysis. This methodology forms the basis of the conventional approach to industrial relations in the UK." The institutional approach visualises economic policy and the 'high' politics of the state as external to the institutions of industrial relations. However, as this paper demonstrates, post-war economic policy and foreign policy played a major role in underpinning the institutional preference for autonomous management practice and free collective bargaining.

By applying the institutional methodology to archive material on the British section of the AACP it is possible to demonstrate that it was in symmetry with the economic and political aims of the government. Moreover, this approach documents how the British section reflected the embedded patterns of behaviour detailed by institutional analysis. This approach will demonstrate that patterns of industrial relations must be seen as an 'end game' that cannot be isolated from a wider framework of economic and political objectives that confront prescriptive mechanisms such as the AACP. The embedded nature of internal institutions in industrial relations must be positioned within the external context that underpins their stability. Patterns of industrial relations are an 'end game' because their institutional workings are affected (in the post-war period, stabilised) by broader economic and political considerations that are external to the institutions themselves. It follows from this position that industrial relations and its institutions cannot be independent causal factors of explanation in successful or unsuccessful economic performance. Alternatively, industrial relations is likely to be one of several factors of influence, thus, as an individual factor its effect can only be marginal. The positions of cause and effect and interdependence are ignored by much of the recent revisionist literature.

The argument and narrative of this article are supported by reference to primary and documentary sources, contemporary studies and the secondary sources of interpretation cited above. ${ }^{12}$ 
THE VIABILITY OF THE BRITISH ECONOMY

The British government used the Marshall Plan as a financial mechanism to secure the sources through which the British state earned its income. There were four such sources; first, a manufacturing base that was disparate in scope, primarily serving the domestic market and varied export markets, a majority in the sterling area; second, freight charges for transport in British ships and the insurances taken out in London on the cargoes - these sources were diminished by the war effort and the associated loss of commercial shipping; third, interest earned on money borrowed in London; and, last, investments in foreign countries. ${ }^{13}$

In 1943, the Board of Trade (BOT) began to examine issues such as industrial efficiency in the light of an eventual victory in the war. ${ }^{14}$ BOT thinking, although it was critical of 'bad management', assumed that the UK's manufacturing base would continue to serve a less than standardised domestic market and varied export markets, particularly in the sterling area. Equally, the BOT assumed that domestic modernisation in industry, including industrial relations, would be managed on a plural and tripartite basis. ${ }^{15}$ The hard currency that was subsequently, if unexpectedly, provided by Marshall Aid served as the basis on which this recovery by continuity was pursued. This was the view that Foreign Secretary Bevin took to the July 1947 Conference for European Economic Cooperation (CEEC). This conference was called by Britain and France in response to the offer of Marshall Aid. In its original guise, the terms of reference for this conference were to organise an integrated pan-European response to the American offer. In contrast to this, the conference was skilfully managed by Foreign Secretary Bevin to ensure that its institutional legacy, the Organisation for European Economic Cooperation (OEEC), oversaw national pathways to recovery. ${ }^{16}$ In the UK's case, the national pathway was designed to secure the UK's residual great power status by maintaining the sterling area and the reserve currency status of sterling. ${ }^{17}$

The British government was prepared to accept a residual great power status in return for autonomy in the organisation of the British recovery programme and associated use of Marshall Aid funds. ${ }^{18}$ This was manifest in four ways. First, in return for the United States reluctantly guaranteeing the reserve currency of sterling, that is, supporting the sterling area as a multilateral trading area, the UK played a major role in internationalising the Cold War throughout western Europe. ${ }^{19}$ Second, the UK secured atomic and nuclear status in an American-dominated NATO. ${ }^{20}$ Third, the British government undertook to enact a productivity programme centred on American best practice in management techniques." Last, significant 
criticism of the UK's deployment of Marshall Aid funds was accepted, but not necessarily acted upon, particularly in relation to the use of 'counterpart funds'. ${ }^{22}$

In summary, the American objective within the Marshall Plan was a long-term restructuring, if not transformation, of European capitalism on an integrationist model. ${ }^{23}$ In contrast to this view, ERP states, and the UK in particular, viewed the Marshall Plan as a mechanism that would underpin a continuity in national policy. ${ }^{24}$ By necessity, within national aims and objectives the outlook was short term. In this respect, the UK's recovery programme is best described as a production or output effort that did not raise the scale of economic efficiency but which did have a considerable impact on labour productivity. The UK's post-war output drive was in economic terms marginal, that is, one sustained at a low capital cost with comparatively low levels of investment in new plant. Here, the volume of output at the existing scale of capital was the main consideration. Hence the concentration on labour productivity within existing capacity. Continuity in the UK's national pathway (one independent of pan-European regulation) necessitated an immediate output drive to maintain export markets. This in turn precluded the apparent need for large scale industrial renewal.

The scale of British manufacturing capacity was not significantly raised by Marshall Aid for three reasons. First, prior to the inception of Marshall Aid the economy was experiencing full employment, and hence it was not necessary to undertake considerable investment to create employment. Second, and related, the vast majority of British Marshall Aid was spent on food and raw materials. In the context of a fully employed manufacturing economy this was the most sensible course of action. The UK had to export manufactures for imports of food and raw materials. The finance of imports is the basis of the third factor. The export-led recovery of output was threatened by the UK's lack of dollars to pay for the necessary imports. Using Marshall Aid to purchase food and raw materials sustained the recovery of output by funding the dollar gap to secure imports.

The following points are offered to substantiate this interim conclusion. First, there is general agreement that the economic effects of the Marshall Plan on the British economy were marginal. ${ }^{25}$ The Bank of International Settlements calculated that in its first year UK Marshall Aid amounted to 2.4 per cent of national income, an injection into the British economy worth about one year's economic growth. ${ }^{26}$ On the basis of UN statistical abstracts, Milward suggests that for the year 1949 UK Marshall Aid represented 5.2 per cent of GNP, or 7.5 per cent taking into account the September devaluation of the pound. A figure of 5.2 per cent in Milward's calculations was enough to finance two and a half years' national growth. ${ }^{27}$ The essential point, however, is that although the economic impact of Marshall Aid was 
marginal it was critical in maintaining the UK's output and export drives. Economic theory is not necessarily useless in this regard; alternatively, its utility is not positive, as economists would like, but demonstrative of how economics is subsumed into the wider aims and objectives of state policy. In financial terms, maintaining the UK's overseas defence commitments and the sterling area were significant cost constraints on the domestic economy. An economic evaluation, confined merely to costs and therefore excluding potential revenue streams, would have suggested an early devaluation of the pound and curtailment of the sterling area. Such a course of action could not prevail, for, as Milward points out, the UK's whole approach to foreign policy and the Marshall Plan was not governed by economics but by perceived political and strategic necessity. In order to sustain the UK's national pathway it was necessary to maintain the level of exports; this in turn legitimised the marginal output drive, which over the short term overcame the need for large scale industrial renewal. Post-war recovery was sustained in a volume-based effort delivered, in the main, by existing plant.

The political economy of the UK's post-war recovery, as mediated by the state's wider policy on the Marshall Plan, was not governed by cost minimisation alone, but also by the generation of revenues that would secure the UK's domestic market and its disparate export markets, many of which were in the sterling area. Closure of the sterling area would have reduced the costs of recovery but would have simultaneously reduced the UK's potential revenue sources because of the extent to which British export markets were geared to the sterling area. ${ }^{28}$ This policy was complemented by an industrial efficiency programme designed to reduce unit labour costs by boosting labour productivity.

In this context, it appears safe to argue that management was encouraged to invest in labour rather than capital equipment. Hence, investment in labour was quantitative rather than qualitative. This was the case even though the economy was fully employed and in the absence of capital reconstruction overtime working became the norm. Calculations indicate that the output drive necessitated considerable overtime working from as early as $1948 . .^{29}$ Overtime working was often necessary because of the difficulty in producing long-run batches of goods when British industry was geared to small batch production without standardisation of products. Equally, the output drive sustained existing plant where improvements in labour productivity flowed from the volume intensity of labour rather than investment in capital to raise the scale and efficiency of plant and labour. Both Middlemas and Milward have described this process as institutional short termism' peculiar to the British state and British management. ${ }^{30}$ Equally, it has been described as all that could be expected from a 
productivity programme that sought to 'Americanise' production management without significantly reforming the framework of management practice. $^{31}$

The UK's successful recovery of output was in large measure marginal, that is, at existing scale. It prevailed in spite of, not because of, American Marshall Planners' wider aspirations within the AACP. It is in these contexts that the failure of the AACP's prescription for the transformation of management practice and industrial relations must be positioned.

\section{III}

THE POST-WAR OUTPUT DRIVE: THE CONSEQUENCES FOR THE AACP

To substantiate the theme and conclusion of the previous section, the argument is grounded within the institutional framework that confronted the AACP, in particular the manner in which the British section embraced the output drive to strengthen its own legitimacy in the eyes of employers and management.

The AACP was set up in order that British manufacturers could learn lessons from American best practice in terms of production management, management accounting and standardisation in production. A transatlantic education programme was initiated which involved 66 team visits to the United States. The teams were made up of industry groups who studied aspects of production management, work organisation and management accounting, and specialist groups who examined issues such as factory layout, palletisation and materials handling. Each team produced an 'American' best practice report. ${ }^{32}$

The main conclusion of the AACP was that improved labour productivity could only be sustained over the long term by higher investment in mechanised production. ${ }^{33}$ This would lead to more efficient production management in materials handling and improved systems of cost and management accounting. In combination, such developments would yield management a more accurate measure of unit costs and facilitate lower costs of production and higher labour productivity over longer production runs. It is generally agreed that the focus of AACP findings centred on the deficiencies of British management in the highlighted areas. ${ }^{34}$ In addition to this point, the manner in which Stafford Cripps, the Chancellor of the Exchequer and co-founder of the AACP, delegated the British section of the AACP to the FBI, BEC and TUC has stimulated much comment. ${ }^{35}$ By taking a hands-off approach, the government enabled representatives of management and employers to set their agenda in the British section. It is generally accepted that this was one of several factors that led to the overall failure of the AACP. Whilst this position is undeniable, it is equally 
undeniable that the failure of the prescription behind the AACP, but not necessarily its British section, represented a victory for the overall aims and objectives of British recovery.

In 1943, the FBI indicated that the UK's likely post-war position would dictate that output and exports must prevail over any significant efforts towards industrial modernisation. Equally, it was argued that the UK would need some measure of protection from American competition through maintenance of the sterling area in Empire and Middle Eastern markets. ${ }^{36}$ By 1948, the British government and industry were not in a position to entertain industrial reconstruction on the scale envisaged by Marshall Planners in the productivity programme. The disaster of sterling convertibility in the summer of 1947 compounded existing materials and capital shortages and drained British dollar reserves. Equally, the lack of hard currency precluded large scale imports of capital equipment and materials from the United States. ${ }^{37}$

These issues are clearly reflected in the papers of the FBI and the British section of the AACP. Norman Kipping, the Director General of the FBI and a joint secretary of the AACP's British section, made it clear to UK trade associations that there would be no American interference with the British section. Essentially, Kipping conceived the British section as a national initiative that excluded the government and the American Marshall Planners in the ECA. In essence, the British section was to represent the interests of the employers, a series of interests that incorporated the institutional representation of organised labour. ${ }^{38}$ In addition, he made it clear that in terms of productivity improvement the main criterion for British industry should be the lowest cost over productivity per man/hour. ${ }^{39}$ The notion of lowest cost over productivity per man/hour appears on first view not to make economic sense unless it is recognised that lowest cost refers to the scale of operations. Labour productivity can be improved at a low capital cost if the volume of output is the main consideration, even though in theoretical terms output is increasing but encountering the law of diminishing returns, that is, sustaining a level of allocative inefficiency. For the government and the British section this was necessary because, in the short term, securing the international viability of the British state precluded raising the scale of British capital by significant new investment in plant. In contrast to this, efforts centred around increasing output at the existing scale of plant by focusing on labour productivity. A move to re-structure, scrap and scale up manufacturing industry through high levels of investment in new plant would have shut British manufacturers out of export markets, weakened the balance of payments and stalled post-war recovery. This combination of effects would have returned the British economy to the situation that prevailed in the summer of 1947. 
AACP documents from 1948 support this position. In the view of the British section measures to increase productivity per man/hour through greater capital investment would, in the short to medium term, have increased units costs. ${ }^{40}$ This was the case because of the loss in output and the set-up costs created by the deployment of new production systems. Equally, new systems would have also required new (American-style) systems of management practice and more institutionalised collective bargaining. This latter point was something to be avoided because it would have strengthened the position of trade unions in the workplace..$^{41}$ As an alternative to this, the British section made it clear that for British manufacturers output must prevail over productivity with quantity rather than the quality or scale of production representing the main imperative. Further, this alternative was necessary because the British market (domestically and overseas) was not standardised in the manner of the American domestic market. ${ }^{42}$ It would appear that these arguments were also designed to defend the relatively small scale of British manufacturing plants that served disparate markets. ${ }^{43} \mathrm{ACCP}$ files indicate that at the time the vast majority of British manufacturing plants employed fewer than 500 workers, with only 60 employing over $5,000 .{ }^{44}$ The British section also documented its doubts about the standardisation of production in industry. Although during the war there had been considerable rationalisation of output, it was in large measure nullified by the diversity of end user requirements in the post-war years; examples are cited from steel manufacture, metal window frames, gear cutting equipment and the production of cooker hobs. ${ }^{45}$

The themes of marginal improvement in productivity at existing scale are also evident in FBI/ACCP documents on regional productivity conferences and exhibitions. Here, the documents detail why the FBI should always retain overall control of the conferences; this was necessary because the main constituency was 'top management', who needed practical information on applications in the current climate not heavily technical explanations. ${ }^{46}$ This view prevailed because technical detail on new systems of work organisation would require the re-negotiation of collective bargaining agreements, for example, new equipment and systems of production would impact on existing demarcation agreements and involve considerable expenditure on training. In the planning stages for conferences in Leicester and Nottingham it was suggested that displays on material handling, storage and factory layout should focus on existing British best practice. In this regard, the objective was too indicate how existing best practice had been adapted in the light of American experience not transformed by it. ${ }^{47}$ It would appear that practical applications in the context of existing best practice reflected the primary consideration of increasing output whilst minimising capital expenditure. 
The draft documents for the AACP's fifth session report in 1952 consolidates further the cost minimisation approach. Both output and productivity were seen to be best improved in the short term by maximum utilisation of existing resources; a direct result of this was considerable overtime working. The draft also establishes that during the previous four years employers had not experienced significant labour inflexibility. However, it was added that, over the longer term, improvement in output and productivity could only be sustained by significantly higher levels of mechanisation in production, more power tools for intermediate stages in production and better factory layout and production organisation. Further, the draft reiterates that over the past four years an increase in capital expenditure by industry would have reduced output and export levels. ${ }^{48} \mathrm{An}$ alternative explanation for employer support of the cost minimisation approach has argued that employer associations and trade associations were imbued with a cartel mentality based on secure markets and that similarly they were obsessed with wage costs. ${ }^{49}$ These sectional interests were only inflamed by placing the FBI and BEC centre-stage in the UK's output-based productivity drive; this positioning secured the FBI's long-standing preference for recovery without significant reconstruction. This recovery was evident in a continuity of management practice, however, the AACP's final report portrayed this as a victory of American managerialism. ${ }^{50}$ Thus, the aims of the British section did correspond with those of the government, but, in addition, its aims secured the narrow material interests of employers. As Carew argues, the victory of American managerialism was considerable in that it incorporated organised labour and the TUC into the productivity programme. ${ }^{51}$ Beyond this, however, the operational mechanics of American management could not dislodge the UK's embedded politics of productivity which the work of the British section actually sustained.

Within the AACP, the TUC was, in the main, supportive, the General Council was active in promoting the productivity drive and in general saw the AACP as a mechanism that would further strengthen the promotion of union membership and collective bargaining. ${ }^{52}$ However, the TUC was guarded in some of its observations; for example, the TUC General Council indicated that in its view there would be no material gain on the United States unless there was much greater capital investment in the UK. It was added that this situation would prevail even taking into account the good increases in output between 1946 and $1949 .{ }^{33}$

In addition, the General Council made reference to material published in The Times. This material suggested that in the absence of significant capital renewal all that could be hoped for from the productivity initiative was a 2-3 per cent increase in productivity per annum..$^{54}$ Equally, the TUC was unhappy with the manner in which the British section appeared to divert 
AACP findings and direct them specifically to top management without full reference to report findings. This was particularly the case in terms of improved mechanisation and training for shop-floor operatives. ${ }^{55}$ Lastly, the TUC was concerned about the manner in which work study was being moulded by the British section, and initiated its own trips to the United States to examine the issue..$^{56}$

The main theme in TUC concern was the sustainability of the output drive in the absence of longer term considerations; in particular, the lack of capital renewal and the consequences of this for shop-floor workers. In its submissions to the AACP, the TUC argued that the UK could not compete with, or be compared with, the United States in any meaningful way. ${ }^{57}$ This was the case because the American manufacturing sector operated on different measures of productivity and productivity improvement. ${ }^{58}$ In addition, the TUC appeared unconvinced that under the auspices of the British section manufacturing industry would be able or inclined to make the necessary improvements on a voluntary basis. ${ }^{59}$

The programme of British visits to the United States sought to demonstrate the benefits and encourage the take-up of two aspects of American management practice that provided a structure for high productivity. First, a 'scientific approach' to management that presented the manager as a technically informed economic and social engineer. Second, institutionalised pluralism in industrial relations centred around institutionalised collective bargaining in the workplace, constitutional trade union recognition and a commitment to job security. ${ }^{60}$

Hoffman, the co-chairman of the AACP and Director of the ECA, argued that the visits programme was of technical importance, but, equally, that the visits would expose the British, and particularly British labour, to the benefits of the 'American way'. ${ }^{61}$ Hoffman's enthusiasm for the visits programme was based on a belief that 'distributional' conflicts between management and labour over productivity and wages were primarily caused by scarcity. ${ }^{62}$ Moreover, scarcity could only be reduced by increasing productivity and productive efficiency through measures such as 'scientific management', business planning and constitutional pluralism in the workplace. $^{63}$

Maier suggests that Hoffman's ambition in prescriptive mechanisms such as the AACP was informed by his apolitical views on productivity improvement; however, this view became ideologically charged in the postwar years as part of the general anti-communist sentiment in US foreign policy. ${ }^{\text {st }}$ The divergence between the American and British sections of the AACP partly resulted from Hoffman's contradictory position; on the one hand, he advocated apolitical benefits (economic and material) of improved productivity for both management and labour, yet he was operating within 
a series of institutions (AACP and ECA) that were increasingly caught up in the wider aims of US foreign policy. Ultimately, the divergence of views between the American and British sections disappeared as Hoffman accepted the national distinctiveness and embedded pattern of the FBI's responses in the AACP. That is, Hoffman accepted that the British section, like the British government, wanted something different from the AACP than he did; however, his 'acceptance' of the distinctively British approach was cushioned by the fact that British management and the TUC came to accept the presence, as a model, of American practices, if not their adoption in the workplace. 'Scientific' management presented managers as 'social engineers' trained in quantitative aspects of production management. A 'scientific' approach to labour and production management was promoted as an impartial and neutral arbiter in the apolitical allocation of labour, not as an 'agent of capital' primarily concerned with the control and subordination of labour in the labour process. ${ }^{65}$

American Marshall Planners in the American section argued that quantitative practices had enabled American management to operate in a 'scientific' and 'Taylorised' manner since the 'New Deal' era. In essence, the New Deal, supplemented by the United States re-armament programme, saw 'scientific' approaches to production management and constitutional pluralism instituted in many large American workplaces. ${ }^{66}$ This movement also saw management develop control and production techniques beyond craft production that was largely regulated by 'simple' managerial controls. Mass assembly production was regulated by technical control strategies that were plurally regulated by the discipline of the assembly line and collective bargaining. ${ }^{67}$ A large number of AACP reports appear to bear out this development and suggest that American management appeared able to mechanise, standardise, monitor and re-structure production with little opposition from the workforce. ${ }^{68}$

A central theme in the visits programme was the assertion that a corporate approach to management practice compelled American firms to develop corporate pluralism in order for the productive potential of standardised assembly lines to be captured. This approach was sustained by deploying managers, labour operatives and supervisors who were trained in technical and quantitative areas such as management accounting, productivity management, materials handling, costing and time and motion study. In response, the TUC and individual trade unions made two points about the generalisation of American 'best practice'. First, a compulsion to institutionalise industrial relations in the workplace demonstrates that a corporate approach to management does not automatically yield higher productivity. Higher productivity has to be extracted through the labour process. Second, contrary to the generalisation of American 'best practice', 
corporate pluralism was not in evidence throughout the US economy. ${ }^{69}$ This point was forcefully made by the TUC in its submissions to the British section; equally, trade unions argued this point in their evaluation of AACP reports. ${ }^{70}$

In general, AACP reports documented the absence of management competence in the areas highlighted above as endemic in British manufacturing, claiming that management practice was unscientific, and demonstrated poor production pre-planning and ineffective work study." Notwithstanding this criticism, the British section successfully legitimised these characteristics as contingent elements within the output drive. American strategists within the AACP, in particular Hoffman, eventually accepted the agenda of the British section. By 1952, it would appear that a plural, if adversarial, pattern of industrial relations was necessary to sustain 'unscientific management' that the British section fought so hard to maintain. ${ }^{2}$ Congressional propaganda on the use of Marshall Aid supports the intransigence of the British section and demonstrates that between 1948 and 1951 the UK's industrial output increased by 25 per cent and was 45 per cent above the 1938 level. ${ }^{73}$ This recovery prevailed despite the failure of the British section to accept American labour and production practices, that is productivity improved without a transformation of management practice. Equally, the recovery of output occurred independently of the British section, its main role was to position its recommendations to support the imperative of sustaining output.

One implication of stability in management practice for industrial relations was a consolidation of the existing framework for job regulation. In rejecting American proposals for management practice, the British section did not even consider the proposals for industrial relations. The records of the British section indicate that as early as September 1948 industrial relations was written out of its agenda. ${ }^{74}$ The British section did, however, concede that industrial relations issues would crop up, and when this occurred any issues should be dealt with by existing collective bargaining machinery. ${ }^{75}$ In addition, organised labour was well placed in the wartime coalition government and the post-war labour governments. The TUC had played an influential role in the development of public policy through its commitment to 'full employment'; in the early 1940s an 'implied social contract' existed with the coalition government, often under the stewardship of Ernest Bevin. ${ }^{76}$ However, after the war there was no specific planning for wage regulation; ${ }^{n}$ equally, there was no attempt to promote shop floor citizenship on the American 'best practice' model. This was even the case in nationalised industry. ${ }^{78}$

The FBI and the TUC presented separate and mutually exclusive defences of free collective bargaining within the British section. For many 
employers, this defence was visualised as a mechanism to re-establish autocratic power in the workplace. ${ }^{79}$ In this context, many employers defined 'free' collective bargaining as free from institutionalised regulation in the workplace. ${ }^{80} \mathrm{~A}$ reliance on national agreements was also seen by some employers as a mechanism to undermine workplace lay activism. For many employers these positions represented one of the major post-war miscalculations made by British management. The miscalculation was particularly evident in sectors that were heavily reliant on overtime working - a central feature of the post-war output drive. This was the case because overtime agreements were, despite managerial preference for national agreements, negotiated at workplace level. ${ }^{81}$

Voluntary collective bargaining, multi-unionism and tripartite mechanisms for improvement in industrial efficiency were widely accepted as essential aspects in the productivity programme and its supportive role in the output drive. One further development did emerge, however. The stability in, and consolidation of, existing patterns in industrial relations was positioned within a fully employed economy. The imperative of output began to shift the focus of collective bargaining away from national agreements to the workplace. ${ }^{82}$ As this shift progressed during the late 1950s, shop stewards emerged as central actors in localised collective bargaining. ${ }^{83}$ Various studies have indicated that localised bargaining was primitive, that is, lacking in formalised procedures; ${ }^{84}$ equally, the studies demonstrate that as a result of full employment organised labour began to focus its demands on money wages through primitive or informal workplace bargaining. Evidence also suggests that employers who were particularly concerned with output, such as those in the car industry, accepted potentially disruptive local pay deals that supplemented nationally agreed norms as a matter of course. The negotiation of this order did not necessarily secure any quantifiable improvements in productivity. ${ }^{85}$ It has been argued that employers were not excessively concerned about this because they were able pass increased costs on to purchasers. ${ }^{86}$ Ministry of Labour estimates for 1948-58 indicate that wage drift (average weekly earnings minus the wage rate component) did not increase significantly over this period, remaining at around 25 shillings (£1.25). Over the same period, the percentage increase in output was 2.3 per cent per annum, whereas unit labour costs grew at four per cent per annum. ${ }^{87}$ These data appear to indicate that any allocative inefficiency in the manufacturing sector, that is, a reliance on overtime working, did not increase during the period. However, as the UK's comparative economic performance declined, workplace 'inefficiencies' such as restrictive practices, previously accepted as marginal, became more significant as comparative scale inefficiencies became evident. ${ }^{88}$ However, management 'inefficiencies', as identified by the AACP, continued. 
It would appear that the movement in industrial relations activity to the workplace flowed directly from post-war recovery, within which the industrial and managerial structure was largely unreconstructed. The system of autonomous collective bargaining was stabilised, and indeed it was further consolidated at workplace level.

The economy, industrial relations and the industrial efficiency programme, the latter under the direction of the British section of the AACP, were all necessarily tuned to the short term. In short, the manufacturing sector and the industrial relations framework delivered employee participation and involvement but also secured what successive governments needed, that is, output. One outcome of strong institutions within industrial relations, particularly at the workplace, is clearly evident here even if it was unrecognised at the time. The strength, stability and viability of the industrial relations system was more enduring than the capacity of the British economy within which it was positioned. It was this strength that stimulated investigation into the industrial relations system as an independent internal factor rather than an internal development sustained by external factors such as economic and foreign policy in the immediate post-war years, and that in turn sustained 'inefficiencies' in management practice. ${ }^{89}$

\section{IV}

THE POST-WAR OUTPUT DRIVE AND REVISIONIST ANALYSIS: THE ISSUE OF INDUSTRIAL RELATIONS

The contemporary period has witnessed a major revisionism in the treatment of the initial post-war period and the longer term decline and comparative failure of the British economy. Prominent in this revision are the approaches taken by Broadberry and Crafts and Barnett. ${ }^{90}$

Broadberry and Crafts suggest that economic policy in the immediate post-war period was successful in dealing with the UK's balance of payments position, yet they argue that the short termism of this policy prevented the introduction of essential reforms in the supply side of the economy, particularly in the industrial relations system. ${ }^{91}$ To support this argument, the authors present an econometric treatment of the UK's productivity performance in comparison to the United States. However, this merely confirms that comparative productivity was weak. This position was established by central actors in the British section as early as $1948 .{ }^{92}$ However, more centrally for the revisionist position, it was the UK's pattern of voluntary collective bargaining and endemic restrictive practices that made long term adjustment in the economy 'marginal to enviable'. ${ }^{93}$

Broadberry and Crafts position their conclusions independently of any 
consideration of management interests. The revisionism in this conclusion is evident in two ways. First, it fails to engage with the positioning of industrial relations as an effect of post-war recovery. As an alternative, the chosen course in post-war recovery is criticised in terms of its consequences without reference to the short term necessity that was defined by the UK's wider objectives within the Marshall Plan. Rightly or wrongly, the focus of post-war recovery was output without significant reconstruction of industry. British manufacturers continued to serve disparate domestic and overseas markets established prior to 1938. AACP files indicate that manufacturing plants of less than 500 workers accounted for 70 per cent of the labour force employed in manufacturing, whereas American manufacturing plants were much larger. The comparatively small scale of British manufacturing plants suggests that regression analysis (the basis on which Broadberry and Crafts' wider assertions about industrial relations is substantiated) designed to capture the scale economies of American plants relative to British plants merely demonstrates that the size and capacity of British plants limited their potential for labour productivity growth in comparison to those in the United States. ${ }^{94}$ The argument that multi-unionism was the main inhibitor of growth in labour productivity is weakened by this evidence; that is, it is more likely that its effect was marginal rather than a scale factor. The relative disadvantage of British plants was obvious to the FBI and the TUC in 1948 and these factors led the British section to dilute or reject American proposals in favour of existing patterns of management practice. ${ }^{95}$ In this context, any significant reform of industrial relations to reflect American practice was unlikely to prevail. Second, the arguments on multi-unionism and associated restrictive practices do not sit well with the documentary evidence or contemporary academic analysis. TUC and AACP records indicate that considerable effort was made on the issue of restrictive practices as part of the productivity programme. ${ }^{96}$ Responses to the TUC's 'Productivity: The Next Step' initiative indicate that, although there was some employer disquiet on restrictive practices relating to overtime, there was not a general concern. ${ }^{97}$ Equally, trade unions and the TUC were not necessarily insistent on the re-introduction of restrictive practices diluted due to wartime conditions. ${ }^{98}$ This pattern is confirmed by a major study of restrictive practices conducted in the immediate post-war period.

Zweig presents a detailed study of job regulation and trade unions in collective bargaining through the vehicle of restrictive practices. ${ }^{99}$ The study examined the situation in building and civil engineering, cotton, iron and steel, printing and engineering. The findings are very revealing and pertinent to the issues under consideration. First, there was no general agreement on the management side in and between sectors on what constituted a restrictive practice. Second, practices such as demarcation 
rules within multi-unionism were not viewed as restrictive by employers because they followed naturally from apprenticeship regulations. These were not viewed as impediments to efficiency, but alternatively were accepted as an integral part of management practice in job regulation. Third, where restrictive practices were identified, many managers had no view on what should be done about them. Some managers indicated that the removal or reform of workplace practices would entail a significant upheaval in management practice. On the whole, it would appear that many restrictive practices were viewed by managers as part of a 'negotiated' order (rather than unilateral craft control) that helped to sustain output. This contemporary empirical evidence suggests that management was not primarily concerned with industrial relations but was more preoccupied with maintaining output. This is not necessarily challenged by Broadberry and Crafts, but the presence of restrictive practices and the industrial relations framework in general are positioned as a central factor in the UK's declining economic performance over the post-war years. ${ }^{100}$ Equally, Broadberry and Crafts assert that restrictive practices were more endemic than the evidence suggests. Further, as the British section and the manufacturing sector were geared towards delivering output, an aim that was successfully prosecuted, the economic effects of any restrictive practices could not have been significant.

In addition to their central argument, Broadberry and Crafts argue that the industrial relations framework inhibited human capital formation. ${ }^{101} \mathrm{It}$ is more appropriate to suggest that this was an effect of the positioning of industrial relations and management practice in the output drive rather than a centrally causal factor. It would appear that improvement in training and development was not forthcoming because existing production systems did not require this.

The position taken by Barnett is much more controversial and superficially convincing, yet unsustainable in the light of the overall argument in this piece. ${ }^{102}$ Barnett argues that the post-war Labour government, followed by its successors, missed a clear opportunity to modernise and transform British industry along the lines of the American model. The 'New Jerusalem' thesis suggests that the welfare state and a public sector complemented by wide scale nationalisation diverted attention from concern with the real economy. This is complemented by the 'Victory' thesis, which argues that the government wanted the best of both worlds, that is, a domestic 'New Jerusalem' positioned within the status of a great power. ${ }^{103}$ In consequence, the government was determined to maintain sterling as a reserve currency. Equally, and by association, the government felt unable to challenge the organised working class. Hence, industrial relations was not reformed because such a move would undermine the role 
of the working class in creating a New Jerusalem. In combination, these domestic and external constraints encouraged the government to squander Marshall Aid on food, domestic housing and public debt retirement. Barnett argues that the government should have terminated the sterling area and injected more Marshall Aid into the domestic economy to re-structure the manufacturing sector on the American model.

This policy was evidently politically impossible under the wider British aims within the Marshall Plan. Moreover, its economic benefits would have been more marginal than the chosen course. For example, termination of the sterling area might have significantly reduced the UK's overseas debt but at the immediate cost of closing many of its export markets and intra-sterling area trade. These losses would have been severely detrimental to the security of the UK's international economic and political viability. Similarly, though the use of counterpart funds for debt retirement did preclude their use for industrial renewal, it has been established that such funds were not a vital source of investment. The recovery of output generated high profit levels, and it has been argued that private sector firms did not need outside sources of finance for investment funds. This argument is supported by Public Record Office files for 1948, which indicate that of $£ 2,000$ million in gross investment nearly 50 per cent was secured by undistributed profits, use of reserves and bank advances. ${ }^{104}$ Equally, in the absence of structural and scale improvements in British manufacturing it is unlikely that industry would have been able to effectively deploy counterpart funds. Further, documentary analysis of the AACP's British section appears to suggest that employers and managers were not supportive of large scale reconstruction. The assertion that this situation prevailed because the government felt unable to challenge this preference ignores the wider political economy of this situation. The government was not motivated to use counterpart funds for debt retirement because it felt unable to challenge trade unions in the manufacturing sector. In contrast to this view, it would appear that securing the viability of the economy (by debt retirement) was directly responsible for securing the viability of the manufacturing sector (by sustaining its export markets).

The main problem with Barnett's approach is the assumption it embodies: the generalisation of decline is written from a position of revisionism that suggests the government promoted a political process in civil society that sacrificed economic performance. In addition, the arguments on industrial relations and restrictive practices are generalised from shipbuilding, the only sector examined in any detail. ${ }^{105}$ Equally, in the specific case of industrial relations, the issue of cause and effect has been reversed; that is, trade unions preventing management from introducing AACP recommendations. The evidence appears to point to the conclusion 
that within the British section of the AACP it was primarily the TUC which was pushing for a more engaged consideration of American proposals, whereas the evidence suggests that any inhibitive attitudes and behaviour displayed by organised labour at the workplace was not seen as a serious concern of management. Moreover, the TUC's guarded criticism of the British sections' response was subsumed into the FBl's overall approach that legitimised the output drive without significant reform of workplace management practice or industrial relations.

\section{$\mathrm{V}$ \\ CONCLUSION}

Institutional stability in industrial relations and management practice during the initial post-war era represented an end-game or institutional effect of the wider economic aims and political objectives of the British state in its engagement with the Marshall Plan. This wider political economy cannot be divorced from the internal institutional mechanisms that operated in the British economy.

The economic and political aims of the British state during the Marshall Plan era were primarily directed towards securing the UK's national pathway to economic recovery. The structure of the UK's manufacturing sector and the markets it served necessitated an immediate recovery of industrial output. Equally, securing the international viability of the British state rested on sustaining markets that accounted for a large proportion of the UK's export trade, and hence termination of the sterling area would have been an inappropriate response. So, too, was the wholesale restructuring of the UK's manufacturing sector. This was the political economy that faced prescriptive mechanisms such as the AACP.

The argument of this paper centres on a sharp distinction between the AACP and its British section. By elaborating and grounding this distinction within the available archive material on the British section, it is clear that its central institutional actors, the FBI supported by the BEC, were supporters, if not advocates, of the overall approach taken by the government. Hence it is not suprising that the AACP's general prescription was a failure. In terms of industrial relations, its failure was assured not only because a reconstruction of British manufacturing was inappropriate, but because the American prescription, however forcefully put, could not dislodge embedded patterns of management and union behaviour. Equally, reconstruction and transformation were incompatible with the wider aims of the British state, whereas a continuity within patterns of management practice and industrial relations did play an important part in securing the recovery of output. 
The lack of industrial relations reform reflects the wider failure of the AACP to reform management practice. Industrial relations was one of the AACP's failures, but not its central failure, which was the inability of American Marshall Planners to appreciate the UK's economic and political aims. Moreover, failure and success must be balanced; the failure of the American-inspired reconstruction represented a success for the aims and objectives of the British state, in particular maintaining its independence from pan-European regulation. It is unlikely that the UK's economic performance would have been any better if the AACP had been successful. The loss of output and markets would have been difficult to make up, especially as the west European market was recovering and becoming increasingly competitive.

The continuity in embedded patterns of management practice and industrial relations was an effect of securing a recovery in output and sustaining the UK's international economic and political viability. Revisionism cannot be corrective in the sense that it can reverse history, neither can the rational actor model inherent to economic theory be wholly successful in isolating one marginal variable or policy choice and then generalising its contribution to wider economic ills. Victory in the Second World War was not lost in the immediate post-war years; independence and sovereignty, the basis on which the UK entered the war, was secured by directing post-war efforts to the international viability of the British state. The recovery in output was successfully prosecuted, and the UK's post-war economic performance relative to its recent past was good and in line with predictions made by central actors in the British section of the AACP. However, comparative economic performance was not so successfully maintained in the 1960s and 1970s. Clearly, output did not decrease during these decades, but comparative levels of labour productivity did decline. ${ }^{106}$ It would appear that many of the revisionist arguments are positioned in this context, and it is here that the absence of industrial relations reform is highlighted as a central factor. However, an archival and institutionally informed analysis demonstrates that trade unions and the TUC were not so much intransigent, but were operative in, or constrained by, embedded patterns of regulation which neither management or trade unions wanted to change.

The recovery of output was successfully prosecuted, yet problems remained in production management and productivity. Industrial relations issues may have headlined these difficulties; however, in the Marshall era as today problems in industrial relations are not centrally causal, but effects of embedded patterns of behaviour in management practice that are in turn distilled through the economic aims and political objectives of the state. 


\section{NOTES}

1. Modern Records Centre (hereafter MRC), Records of the Anglo-American Counncil for Productivity/Federation of British Industry (hereafter AACP/FBI Papers), MSS 200F/3T/328/1 note on inaugural meeting of AACP British Section. See also AACP Final Report (London, 1952), and G. Hutton, We Too Can Prosper (London, 1953).

2. A. Carew, Labour Under the Marshall Plan (Manchester, 1987)

3. Ibid. It has been commented upon that Carew does not define the term 'scientific management' precisely. See J. Tomlinson and N. Tiratsoo, Industrial Efficiency and State Intervention 1939-1951 (London, 1993), Chapter 7. It would seem safe to conclude that the terms 'scientific management' or 'scientific approaches to management' imply the use of standardised units in production, standardised costing of components and final units, work study and improved production management in terms of assembly line production and factory layout.

4. M. Hogan. The Marshall Plan: American, Britain and the Reconstruction of Western Europe 1945-1952 (Cambridge, 1987); C. Maier, "The Politics of Productivity: The Foundations of American Foreign Economic Policy after World War Two', International Organisation, Vol.31 (1977), pp.607-35; idem, In Search of Stability (Cambridge, 1987). Maier argues that the United States sought to impose a pan-European pattern of 'productivity politics', but was forced to concede that the politics were actually defined in and sustained by embedded patterns of behaviour in national pathways.

5. Tomlinson and Tiratsoo, Industrial Efficiency.

6. C. Barnett, The Audit of War: The Illusion and Reality of Britain as a Great Nation (London, 1986).

7. C Barnett, The Lost Victory: British Dreams British Realities 1945-1950 (London, 1995), Chapter 19, 'Marshall Aid', pp.373-9. Official records indicate that of the $\$ 3,000$ million that the UK received under Marshall Aid, 40 per cent was spent on food, 40 per cent on raw materials, seven per cent on investment equipment, 12 per cent on oil and eight per cent on equipment; HMSO, Recovery Record: The Story of Marshall Aid (London, 1951). Barnett does not comment on the need for a fully employed manufacturing economy to import food and raw materials.

8. S. Broadberry and N. Crafts, 'British Economic Policy and Industrial Performance in the Early Post-War Period', Business History, Vol.38 (1996), pp.65-91; idem, 'Explaining Anglo-American Productivity Differentials in the Mid-20th Century', The Oxford Bulletin of Economics and Statistics, Vol.52 (1990), pp.375-402.

9. The institutional approach to industrial relations bas been generalised in a series of highly influential texts, see below. In addition, Clegg, a central advocate of this approach, was a member of the 1965 Royal Commission on Industrial Relations. Equally, Flanders, a second central advocate of this approach, gave evidence to the Commission. In addition, Flanders was editor of Socialist Commentary, a journal through which American Marshall Planners sought to generalise their ideas on productivity and productivity bargaining in the workplace. The institutional approach to industrial relations was first laid out in $A$. Flanders and H. Clegg (eds.), The System of Industrial Relations in Great Britain (Oxford, 1954). The approach as been sustained and updated in successive editions of this text: $H$. Clegg, The System of Industrial Relations in Great Britain (London, 2nd edn. 1970 and 3rd edn. 1976); idem, The Changing System of Industrial Relations in Great Britain (Oxford, 1979); G. Bain (ed.), Industrial Relations in Great Britain (London, 1983); and P. Edwards (ed.), Industrial Relations: Theory and Practice (Oxford, 1995).

10. Clegg, Changing System, Chapter 11.

11. Flanders and Clegg, System, Chapters 1 and 5; Clegg, Changing System, Chapter 1. This view has become the conventional wisdom, but has been criticised by other industrial relations specialists; see R. Hyman 'Pluralism, Consensus and Collective Bargaining', British Journal of Industrial Relations, Vol.16 (1978), pp.16-40.

12. Documentary research for this contribution was undertaken in the MRC, University of Warwick, and the Stack Collection at the University of Leicester (hereafter LUSC). A key contemporary study, from the post-war period which is cited later, is F. Zweig, Trade 
Unions and Productivity (Oxford, 1951); Secondary sources are Barnett, Audit (London, 1986) and Victory (London, 1995); Broadberry and Crafts, 'Performance'; Carew, Labour; Tomlinson and Tiratsoo, Industrial.

13. A. Dulles, The Marshall Plan (Providence, RI, 1993). This is an interesting source, as Dulles was a Marshall Planner. He wrote this book in 1947, though it was not published until 1993. Dulles pushes a supra-national line and suggests that the UK's existing industrial and managerial structures must be overwhelmed by American 'best practice'. That is, national pathways cannot prevail if European recovery is to be effective.

14. The Board of Trade (BOT) was in conflict with the Ministry of Labour and National Service (MLNS) and the Treasury over particular aspects of industrial policy and industrial relations policy. It appears that the BOT initially favoured an interventionary policy in both areas. For example, industrial policy based around removing 'inefficiency' deriving from cartel attitudes to production, particularly in relation to Empire markets. In terms of industrial relations policy, the BOT proposed more intervention to make collective bargaining work 'efficiently', whereas the MLNS and the Treasury both favoured a return to free collective bargaining. See L. Johnman, 'The Labour Party and Industrial Policy 1940-1945', in N. Tiratsoo (ed.), The Atlee Years (London, 1991); K. Middlemas, Power, Competition and the State (London, 1986), Vol.1, pp.87-105. Summary views of BOT policy in Board of Trade journal; copies of wartime and immediate post-war years in LUSC OFF PUBS UK/TRA B4096

15. Middlemas, Power, Competition and the State.

16. Useful accounts of Bevin's approach to the conference include A. Bullock, The Life and Times of Ermest Bevin (London, 1983), Vol. 3; D. Calleo and B. Rowland, America and the World Political Economy: Atlantic Dreams and National Realities (Indiana, 1973); W. Cromwell, 'The Marshall Plan and the Cold War', Review of International Studies (London, 1982), pp.233-49; Hogan, Marshall Plan; V. Der Beugal, From Marshall Plan to Atlantic Partnership: Integration as a Concern of American Foreign Policy (Amsterdam, 1966).

17. The UK's great power status was residual for two reasons. First, the UK sought to maintain its great power status in the context of an international political economy dominated by two superpowers; hence it attempted to become a European great power by pursuing foreign policy objectives through the domestic economy; for a summary of this argument, see J. Bulpitt, 'The European Question', in D. Marquand and A. Seldon (eds.), Ideas that Shaped Post-War Britain (London, 1996); A. Deporte, Europe Between the Superpowers (New Haven, CT, 1987). Second, great power status necessitated an independent national economy, that is, one free from pan-European regulation. This required the maintenance of the sterling area in order to preclude the UK being pulled into a pattern of pan-European regulation. In consequence, it was essential that the UK's Marshall Aid area included sterling area states. Hence great power status was residual because it rested on US finance, which was reluctantly given. See Hogan, Marshall Plan, pp.168-75; C. Newton, 'The Sterling Crisis of 1947 and the British Response to the Marshall Plan', Economic History Review (1984), pp.391-408.

18. S. Strange, Sterling and British Policy: A Political Study of an International Currency in Decline (Oxford, 1971), p.62. Strange argues that the UK's status as 'great power' became residual in 1944, the date at which the US became the 'ultimate guarantor' of the sterling area.

19. Hogan, Marshal Plan; Strange, Sterling. For more detail on the UK's role in internationalising the Cold War, see G. and J. Kolko, The Limits of Power: The World and United States Foreign Policy 1945-1954 (NewYork, 1972), Chapters 16-18.

20. For a definitive account of this anti-federalist view, see R. Osgood, NATO: The Entangling Alliance (Chicago, IL, 1962).

21. For a documentary survey, see J. Tomlinson and N. Tiratsoo, Industrial Efficiency (London, 1993); for a journalistic account from the time, see Hutton, We Too Can Prosper.

22. Counterpart funds were a central component of the Marshall Aid programme, they represented the domestic currency equivalent of the dollars made available to European states in the programme. Essentially, the availability of counterpart funds meant that west 
European purchasers of dollar goods paid their home government in the domestic currency; thereby, a government could accumulate large balances equivalent to the value of dollars received. The ECA recommended that counterpart funding be used for domestic investment in manufacturing industry to cover large scale scrapping and re-equipping. However, the ECA recognised that it might be necessary to use counterpart funds for debt retirement, the use to which the vast majority of UK funds were put. See W. Brown and R. Opie, American Foreign Assistance (Washington, DC, 1954), p.244. For a specific discussion of the UK's deployment of Marshall Aid counterpart funds, see J. Tomlinson, 'Corelli Barnett's History: The Case of Marshall Aid', Twentieth Century History, Vol.8 (1997), pp.222-38.

23. See Dulles, Marshall Plan; Hogan, Marshall Plan. For a more specific discussion of this view, see M. Hogan, 'American Marshall Planners and the Search for a European NeoCapitalism', American Historical Review', (1985), pp.44-73.

24. A. Milward, The Reconstruction of Western Europe, 1945-1951 (London, 1984).

25. For a review of the major pieces on this issue which contrasts the positions taken by Hogan and Milward, see D. Ellwood, 'The Impact of the Marshall Plan' (Review Article), History: The Journal of the Historical Association (1989), pp.427-36.

26. Bank of International Settlements, Annual Reports, 1945-1950, Basle, Switzerland, LUSC, PER 330B 1147.

27. Milward, Reconstruction, pp.94-7.

28. A. Cairncross, The Years of Recovery, 1945-195I (London, 1985), Table 4.1, p.66. Here it is established that sterling area markets accounted for 45 per cent of UK exports in 1938, 45 per cent in 1946 and 48 per cent in 1950 . It is difficult to see how these markets could be replaced in the short to medium term. Equally, the economic damage created by the loss of these markets would have been far greater than the economic benefits of a reconstructed manufacturing sector with much weaker access to other markets.

29. I. Clark, 'The State, Regulation and Industrial Relations' (unpublished Ph.D. thesis, University of Leeds, 1996).

30. Middlemas, Power, Chapter 4; Milward, Reconstruction, Chapter 14.

31. Carew, Labour.

32. AACP reports $1-66$. Available in Leicester University Library. Original and some draft versions available in MRC.

33. Tomlinson and Tiratsoo, Industrial Efficiency; for an earlier airing of this view, see Hutton, We Too Can Prosper.

34. See AACP Final Report (London, 1952), pp.31-6; Simplification in Industry Report (London, 1949); Materials Handling Report (London, 1949), p.9; and Management Education Report (London, 1951), pp.5, 19-20. For secondary source commentary, see Carew, Labour; Tomlinson and Tiratsoo, Industrial Efficiency; Hutton, We Too Can Prosper.

35. Tomlinson and Tiratsoo, Industrial Efficiency, pp.133-5.

36. MRC MSS 200F/3T/328/1. AACP/FBI Papers AACP 5/3, Oct. 1948, UK section notes and memos on aims and objectives of British section - in UK markets and export markets continuity in production systems and output more important than capital investment or the quality of output; for secondary source interpretation on wartime position of the FBI, sce Middlemas, Power, pp.100-101.

37. Newton, 'The Sterling Crisis'. Sterling convertibility was a condition of a previously negotiated loan. For specific details, see R. Clarke, Anglo-American Collaboration in War and Peace 1942-1949 (Oxford, 1982); for a general treatment of both issues, see A. Cairncross, The Years of Recovery (London, 1985), Chapters 1, 2 and 6.

38. MRC MSS 200F/3T/328/1, 25 Aug. 1948, AACP/FBI Papers, Kipping to British panel 'no US inquisition' 'put our programme to the Americans, our progamme in the context of our manufacturing industry'. For a more conceptually based comparative and historical assessment of American production systems and their application and suitability to the British economy, see J. Zeitlin, 'Americanisation and its Implications', Business and Economic History, Vol.24 (1995), pp.277-86. 'Regulation' approaches to the post-war period highlight the successful introduction of mass production and mass consumerism 
associated with 'Fordism' and 'Fordist' production systems. These two sources throw some doubt on the viability of that model in the immediate post-war years; sce I. Clark, 'The State and New Industrial Reiations', in I. Beardwell (ed.), Critical Essays in Contemporary Industrial Relations (Oxford, 1996), p.44.

39. MRC, MSS 200 F/3T/328/1, AACP/FBI Papers, Notes and Memo to Trade Associations, 16 April 1948.

40. MRC, MSS200F/3T/328/1, AACP/FBI Papers, AACP S/3, 26 Oct. 1948.

41. MRC, MSS 200 F/3T/26/3, AACP/FBI Papers, White (FBI Technical Officer, London) to Kipping, 6 Nov. 1950, re-planning of AACP conference in Nottingham 'no joint union management discussions' Kipping to Spencer (Spence Ltd, Basford, Nottingham), 23 Nov. 1950 re-productivity exhibitions and conferences 'keep management problems and interests on productivity away from trade unions'.

42. MRC, MSS 200 F/3T/328/1, AACP/FBI Papers, AACP Oct. 1948, 'Industrial Standardisation in the UK'.

43. Ibid.

44. Ibid., AACP, 'Size of UK Manufacturing Plants', 14 Sept. 1948.

45. Ibid., AACP, Oct. 1948, 'Industrial Standardisation in the UK'.

46. MRC, MSS 200F/3T/3/26/3, AACP/FBI Papers, White to Kipping, 11 Aug. 1950.

47. MRC, MSS 200F/3T/328/1, AACP/FBI Papers, Kipping to White, 11 Aug. 1950, and Herbert (Viyella, Nottingham) to Houghton (regional officer, central office of information, Nottingham, 8 Sept. 1950 re TUC (Leicester). Herbert indicates initial support for TUC suggestions for greater worker involvement in the conferences. The FBI response was unfavourable, White to G. White (FBI, Leicester) TUC (Leicester) and Herbert are 'jumping the gun' 'we don't want this'. Eventually Dearing (TUC, Leicester) and Herbert concur with the FBI/AACP view see Dearing to G. White, 10 Nov. 1950.

48. MRC, MSS 292/552/32/2, AACP/FBI Papers, Draft Document, 5th session, 21 April 1952.

49. Middlemas, Power, pp.4, 94 (on employers' preference for relative inefficiency) and p.97 (on employer's suspicion of new equipment and new product design and their overall preference for sheltered markets at home and 'lmperial Preference').

50. AACP Final Report (London. 1952), see appendix 2, p.31, 'Impact of the Reports on Industry'; the main benefits that are highlighted here concentrate on improvements to factory layout and in the seven industry groups reviewed there is little mention of management techniques or management practice. However, there was an assumption that engagement with, and the take-up of, American management techniques was now the norm.

51. Carew, Labour.

52. MRC, MSS 200 F/3/T/328/1, AACP/FBI Papers, AACP General Council 9, 7 Oct. 1948, TUC submission and views on AACP rubric and mission 'The AACP should be a joint management-labour effort' to incorporate joint industrial councils and joint industrial committees, i.e. labour relations issues should be handled through existing collective bargaining machinery (as indicated by AACP chairman 25 Aug. 1948).

53. MRC, MSS 292/552/32/2, TUC Registry Files, internal memo, dated 9 May 1948.

54. MRC, MSS 200 F/3T/328/1, AACP/FBI Papers, Oct. 1948. AACP Industrial Capital Investment; for full details see The Times, 15-16 Oct. 1948, 'The Re-Equipping of Industry'; 22 Oct. 1948, 'British Plans for the First Year of Marshall Aid'; 23 Oct. 1948, 'The Chancellor's Dilemma'; all three articles are generally supportive, if sceptic, in the suggestion that output increases over the pre-war years are not as significant as the need to maintain improvement in productivity. The articles also refer to the AACP not as the productivity council but as the 'output council'.

55. MRC, MSS 292/552 373/2B, TUC Registry Files, TUC correspondence, TUC (Leicester) to Hutton, 1 Sept. 1950; Kipping to White, 6 Nov. 1950. In addition, see TUC correspondence about the Hutton book on the AACP. The TUC was unhappy with the manner and format of the book, particularly the fact that it contained too much author opinion, was too journalistic and did not refer to the actual reports in any detail, yet overall the book made simple comparisons with the United States. See Fletcher to Tewson, 22 July 1952, and Fletcher to Williamson, 28 Aug. 1952, where it is highlighted that restrictive 
practices receive much negative interpretation without full consideration as to why they might be necessary. Equally, there is much criticism of the later chapters and a suggestion that they need to be re-written, e.g., 'British worker lethargy as a form of psychological sickness'. The TUC production department remained unhappy with the revised version of the book, see Fletcher to Williamson, 9 Jan. 1953, 'OK but not as we'd have written it'.

56. MRC, MSS 292/557 91/5, TUC Registry Files, 'Productivity: The Next Step' draft details of TUC conferences on the question; equally documents from individual trade unions on the issue of restrictive practices, see final version in 'Productivity' report to the General Council special conference of the Trade Union Executive Councils, Nov. 1948.

57. MRC, MSS 200 F/3T 328/1, AACP/FBI Papers, see notes by Fletcher (TUC production department) on US productivity statistics. The material indicates that in the US productivity is measured in terms of man hours per unit of output, a practice not used in the UK. See also MRC, MSS 200 E/3/T328/13, AACP correspondence on reports from US Bureau of Labour Statistics - this information was sent for industry to comment on. Representatives from British Sugar responded saying they were unable to understand the figures, in particular, 'Trends in Man Hours Per Unit of Output'.

58. MRC, MSS 200F/3T328/1.

59. MRC, MSS 200F/3T/328/1 ESO/1.

60. Maier, In Search of Stability.

61. P. Hoffman, Peace Can be Won (New York, 1951), pp.95-6, 125-6.

62. Phillip Reed, the head of the American section, shared this view. Maier documents the development of 'apolitical' approaches to productivity in American production policy by tracing it back to the 1918 war production board and Herbert Hoover's 'Business Associationism' through to the inter-war Committee on Economic Development organised by progressive members of the business community, including Hoffman. Thus it appears safe to conclude that what Maier means by 'apolitical' is that the ideas came not from the American government but American businessmen. They were then appropriated by the American government and positioned within their wider foreign policy concerns in the immediate post-war years. Maier, In Search of Stability, pp.127-30.

63. 'Regulation' approaches to management practice and production systems in the post-war period visualise the 'apolitical' approach to productivity as a method of containing organised labour by incorporating trade unions into Fordism. However, the extent to which British management, production systems and industrial relations were Fordist is the subject of intense debate. The main weakness in the regulation approach is its conceptual generality and abstraction, that is, a lack of empirical and documentary material to substantiate its claims. For a supportive view of regulation, see B. Jessop, 'Regulation Theory', in P. Arestis and M. Sawyer (eds.), The Elgar Companion to Radical Political Economy (Aldershot, 1994). For a more sceptical view, see R. Hyman, 'Economic ReStructuring, Market Liberalism and the Foundations of National Industrial Relations Systems, in R. Hyman and A. Ferner (eds.), New Frontiers in European Industrial Relations (Oxford, 1994).

64. See Maier, In Search of Stability, Chapter 3. Maier is primarily concerned with how patterns of national distinctiveness, if they continue, as in the case of the AACP's British section, may undermine common structural bases of operation for liberal democracies; a case in point is the divergence between Hoffman's 'apolitical' approach to productivity and the embedded position of British employers in the British section of the AACP. Hence Maier attempts to demonstrate how technical innovations such as 'scientific management', Hoffman's 'apolitical politics of productivity' and even 'Fordism' do not so much influence management practice and industrial relations, but rather how their 'apolitical appeal' influences models of economic and social organisation. For further discussion of Maier's approach and more detailed application of it to the Marshall Plan, see F. Longstreth, 'Historical Political Economy and Liberal Democratic Capitalism', Economy and Society, Vol.19 (1990), pp.95-119.

65. However, as Carew points out, the vast majority of AACP trips to the United States were confined to Eastern Seaboard states where institutionalised pluralism was in evidence. As Carew argues, it was not in evidence throughout American industry. See Carew, Labour, 
Chapter 9. For primary source material on this issue, see MRC, MSS 292/557 91/5, TUC Registry Files, 'National Federation of Building Operatives responses to TUC productivity inquiries and the AACP Buildings report'. The following points are made: the American construction industry exhibits high wages in regulated areas and breadline wages in unregulated areas; the geographical area covered by the report was confined to the Washington DC area; overt discrimination and low wages still existed in many southern states. The submission concluded that there is little to learn from the report other than that UK wages are low in comparison.

66. See R. Edwards, Contested Terrain: The Transformation of the Workplace in the Twentieth Century (London, 1979).

67. Ibid.

68. AACP, Iron and Steel Report (London, 1952), pp.16-17; Steel Construction Report (London, 1952), pp.17-19; and Internal Combustion Engines Report (London, 1950), pp.18-19.

69. Carew, Labour, Chapter 9. See also H. Harris, 'The Snares of Liberalism? Politicians, Bureaucrats and the Shaping of Federal Labour Relations in the United States 1915-1947', in S. Tolliday and J. Zeitlin (eds.), Shop Floor Bargaining and the State: Historical and Comparative Perspectives (Cambridge, 1985).

70. MRC, MSS 292/557 91/5, TUC Registry Files, National Federation of Building Trade Operatives report on AACP trip to US.

71. See AACP, Final Report (London, 1952), pp.31-6; Simplification in Industry Report (London, 1949); Materials Handling Report (London, 1949), p.9; and Management Education Report (London, 1951), pp.5, 19-20. This position is commented upon generally, that is, beyond the confines of the AACP, by B. Elbaum and W. Lazonick (eds.), The Decline of the British Economy (Oxford, 1986), opening chapter by the editors.

72. Hoffman, Peace Can be Won, and H. Phelps Brown, Britain and the Marshall Plan (London, 1988), Chapters 5, 6 and 7.

73. I. Wexler, The Marshall Plan Re-Visited (Connecticut, 1983), p.94.

74. MRC, MSS 200F/3T/328/1, AACP/FBI Papers, AACP first meeting, 25 Aug. 1948.

75. Ibid. The TUC were unhappy with the inclusion of the BEC because industrial relations matters were not a central area of concern; see AACP General Council memo, 7 Oct. 1948, however, the BEC was admitted on 14 Oct. 1948.

76. TUC, Interim Report on Post-War Reconstruction (London, 1944).

77. See J. Hinton, Shop Floor Citizens: Engineering in 1940's Britain (Aldershot, 1994), pp. 200-205.

78. Ibid.

79. Ibid.

80. It was for this reason that the FBI and individual managers were so concerned to prevent the more positive aspects of AACP reports on workplace collective bargaining getting through to workers in productivity exhibitions.

81. See W. McCarthy, The Role of Shop Stewards in British Industrial Relations, Donovan Research Paper number 1 (London, 1966), pp.12-13, for discussion of the situation in engineering.

82. There is only passing mention of this in the Donovan Report itself (p.38). HMSO Cmnd. 3623 (1968). However, it is detailed in McCarthy, The Role of Shop Stewards. Neither considers the influence of external factors in this development.

83. McCarthy, Shop Stewards; Donovan, Report. It has been pointed out that the Donovan research was biased towards particular industries, notably engineering and shipbuilding, in which the role of the steward was particularly developed. See H. Turner, 'The Royal Commission's Research Papers', British Journal of Industrial Relations, Vol.6 (1968), pp.346-59.

84. Donovan, Report, pp.29-35: McCarthy, Shop Siewards; J. Goodman and T. Whitlingham, Shop Stewards.

85. For a specific case study, see S. Tolliday, 'Government, Employers and Shop Floor Organisation in the British Motor Industry', in Tolliday and Zeitlin (eds.), Shop Floor.

86. G. Reid, 'An Economic Comment on the Donovan Report', British Joumal of Industrial 
Relations, Vol.6 (1968), pp.303-15; H. Turner, 'The Donovan Report', The Economic Journal, Vol.79 (1969), pp. 1-10.

87. J. Dow, The Management of the British Economy 1945-1964 (Cambridge, 1964), pp.349, fig. 13.5, p. 347 for data and commentary on output figures and unit labour costs.

88. Comparative scale inefficiencies became evident in the declining share of world trade, which fell from 24 per cent in the early 1950s to 14 per cent by the early 1960 s; see National Institute Economic Review (Feb. 1972). In addition, the introduction of sterling convertibility in 1958 exposed the UK's reliance on sterling area markets, markets that were not growing as fast as those in western Europe.

89. Political Quarterly (1956), special edition on trade unions under the general heading 'Trade Unions in a Changing World', and the Scottish Journal of Political Economy (1958), under the general heading 'Wage Policy and Inflation'. For some critics, the institutional position laid out in these special editions was further substantiated in the Donovan Report; Reid, 'An Economic Comment'; Turner, 'The Donovan Report'; R. Crossley, 'The Donovan Report: A Study in the Poverty of Historicism', British Journal of Industrial Relations, Vol.6, pp.296-302. All three of these contributions suggest that the institutional method of industrial relations analysis was too descriptive and failed to grasp how post-war economic policy and economic conditions created what the Royal Commission termed 'disorder'. It would appear that in combination Crossley, Reid and Turner were all arguing that the separation of industrial relations, as an academic subject, from its position within post-war economic policy, created, at workplace level, mechanisms for negotiated order. The order only became disorderly once economic conditions underpinning it deteriorated. Thus, it was not a failure of the industrial relations system that created 'disorder', but deteriorating economic performance. One can add a further inference to this point: seeking to correct 'disorder' without addressing economic factors beyond industrial relations (as it was practised by employers and trade unions), e.g. management practice, investment levels and rates of technological diffusion could not create 'order' in industrial relations, see I. Clark, 'The State and New Industrial Relations', in I. Beardwell (ed.), Critical Essays in Contemporary Industrial Relations (Oxford, 1996).

90. Broadberry and Crafts, 'Industrial Performance'; Barnett, Audit; idem, Lost Victory.

91. Broadberry and Crafts, 'Industrial Performance', p.87.

92. MRC, MSS 200 F/3T/328/1, AACP/FBI Papers, AACP Industrial Capital Investment, Oct. 1948 , TUC references to growth potential of British economy.

93. Broadberry and Crafts, 'Industrial Performance', p.87.

94. Ibid., pp.80-85.

95. MRC, MSS $200 \mathrm{~F} / 3 \mathrm{~T} / 328 / \mathrm{l}$, AACP/FBI Papers, AACP, Size of UK manufacturing plants, Oct. 1948.

96. MRC, MSS 292/557 91/5, TUC Registry Files, full details of TUC conferences and the responses of a large number of trade unions to TUC inquiries on restrictive practices. For example, National Society of Pottery Workers, 11 March 1949; the TGWU, 2 May 1949; the Iron and Steel Trade Confederation, 12 March 1949; and the Printing and Kindred Trades Association, 18 Oct. 1949. These and many other responses either fail to cite restrictive practices as a serious issue or concede that management are only pushing on restrictive practices that seek to restrict overtime, especially if the latter is compulsory.

97. Ibid.

98. MRC, MSS 292/557 91/5, TUC Registgry Files, TUC notes on the 'Productivity: The Next Step' Programme. There were two main themes in TUC policy on restrictive practices. First, definitional, for example apprenticeship regulations were often inaccurately termed restrictive praclices. In addition, the TUC argue that there were many management restrictive practices that were not recorded or accepted as being present, for example, output restrictions and restrictive pricing arrangements were cited. Second, the TUC was only interested in 'democratic' practices that served the interests of workers. 'Democratic' was defined in the context of collective bargaining. If a practice was no longer necessary it would be removed from the bargaining agenda, for example restrictions on compulsory overtime or dilution of the skill level by the entry of unqualified workers. In many cases practices in these areas had been relaxed due to wartime conditions and had not 
significantly weakened the position of the skilled workforce.

99. F. Zweig, Trade Unions and Productivity (Oxford, 1951). Broadberry and Crafts, 'Industrial Efficiency', cite Zweig in one footnote (51) but do not engage specifically with his argument and data; equally they appear to use his survey material in support of their criticism of Tiratsoo and Tomlinson, see below. The central point in Zweig's work is that management did not appear to be excessively concerned with restrictive practices. Further, Zweig demonstrates that the term was used without accurate definition. It would appear that this was part of a larger ${ }_{i}$ problem; management fell back on the term 'restrictive practice' to describe anything that inhibited production, yet restrictive practices operated within the wider pattern of management practice.

100. Zweig, Trade Unions. In addition, Broadberry and Crafts contest the position of N. Tiratsoo and J. Tomlinson, 'Restrictive Practices 1945-1960: Myth and Reality', Business History. Vol.36 (1994), pp.65-84.

101. Broadberry and Crafts, 'Industrial Performance', pp.68-94.

102. Ibid.; Barnett, Audit; and, more particularly, idem, Victory.

103. Barnett, Audit; idem, Victory.

104. J. Tomlinson, Economic Planning: Debate and Policy in the 1940s', Twentieth Century History, Vol.3 (1992), pp.154-74.

105. Barnett, Victory, pp.34-8 and 299-303.

106. N. Crafts, 'Reversing Relative Economic Decline? The 1980s in Historical Perspective', Oxford Review of Economic Policy, Vol.7 (1991), pp.81-98, Table 1, Productivity Growth in the Business Sector of OECD countries (per cent per year). The table indicates that over the periods 1960-73 and 1973-79 the UK's labour productivity increased by 3.5 per cent per year and 1.5 per cent per year respectively. In comparison. Germany's increases were 4.6 per cent and 3.4 per cent; France's were 5.4 per cent and 3.0 per cent. (This table is based on J. Kendrick, 'International Comparisons of Productivity Trends and Levels', George Washington University Discussion paper (1990), pp.90-102.) 